\title{
DOI 10.36074/logos-10.09.2021.66 \\ СУТНІСТЬ УПРАВЛІНСЬКОї ДІЯЛЬНОСТІ КЕРІВНИКА РЕГІОНАЛЬНОЇ ПСИХОЛОГІЧНОЇ СЛУЖБИ СИСТЕМИ ОСВІТИ
}

\author{
Лунченко Надія Вікторівна \\ науковий співробітник \\ Український науково-методичний центр практичної психології \\ і соціальної роботи \\ УКРАÏHA
}

Діяльність керівника психологічної служби обумовлена і регламентована нормативними документами про психологічну службу системи освіти, вимогами скоординувати та активізувати роботу працівників психологічної служби, удосконалити систему підвищення їх кваліфікації, надати їм кваліфріковану науково-методичну допомогу. Враховуючи це, професійну діяльність керівника психологічної служби можна визначити як багатоаспектну: управлінську, науково-методичну, дослідницьку, виховну та як діяльність практичного психолога. Таким чином, її доцільно характеризувати як взаємодію управлінського, науково-методичного та професійно-фрахового компонентів.

Слід відмітити, цілісність професійної діяльності керівника психологічної служби забезпечується взаємодією вище означених компонентів. Як свідчить досвід, на практиці керівники не завжди враховують всі компоненти та їх взаємозв'язок, що призводить до зниження ефективності та порушення цілісності його праці.

У своїй діяльності керівник психологічної служби не повинен звужуватись лише до сорери використання менеджменту в управлінні ("шкільний менеджмент", "педагогічний менеджмент", "психологічний менеджмент"...), а вміти бачити фрункціонування психологічної служби в її цілісності та взаємозв'язку всіх компонентів, включаючи вертикальні й горизонтальні рівні, комунікативні та взаємопов'язані процеси, що діють в межах освітньої системи регіону, тобто мова повинна йти про "освітній менеджмент" як в управлінні психологічною службою, так і освітньої системи регіону в цілому.

Враховуючи специфіку психологічної служби системи освіти в сучасних умовах, визначаємо такі особливості управління нею:

- інноваційний характер, тобто постійний пошук і введення в практику управління нових елементів, підходів тощо, які забезпечать якісні внутрішні та зовнішні зв'язки системи;

- інформативність, тобто максимальне всебічне інформування про стан системи (кількісні та якісні показники);

- прогностичність, що відображає процеси прогнозування та розвитку управління якістю післядипломної педагогічної освіти в регіоні;

- рефлексивність як конструктивний фрактор здатності системи до пошуку, оцінки та розуміння досягнутих результатів.

Основні принципи, на яких базується процес професійного розвитку керівників регіональних психологічних служб

1. Швидкого реагування освітньої системи на динаміку та особливості розвитку економіки країни й регіону, сприйнятливості до освітніх інновацій. 
2. Регіоналізації системи післядипломної педагогічної освіти та врахування запитів, інтересів керівників районних (міських) психологічних служб як усієї області, так і кожного району (міста), зокрема економічного, соціальнокультурного розвитку територій.

3. Широкого демократизму післядипломної педагогічної освіти регіону, доступності, відкритості запропонованих інститутом фрорм професійного розвитку керівників психологічних служб.

4. Неперервності освіти, постійного заняття самоосвітою як найвищим проявом професійної рефлексії, усвідомлення власної місії та професійної діяльності.

5. Адекватності рівня домагань науково-методичних служб умовам праці практичних психологів і соціальних педагогів, матеріально-технічному забезпеченню в закладах освіти району (міста).

6. Провідної ролі принципу інтеграції як такого, що передбачає взаємозв'язок, взаємопроникнення та взаємодоповнення всіх принципів безперервної освіти, не виключаючи домінування того чи іншого в залежності від пріоритетів стратегічного чи тактичного планів розвитку особистості та враховуючи при цьому наступне - кількість повинна переходити в якість.

Оволодіння знаннями з теорії управління та вироблення відповідних управлінських навичок здійснюється у три етапи:

на I етапі - методологічному - головна увага приділена розкриттю основ науки управління, зокрема освітнього менеджменту, формуванню вміння системного бачення проблеми та її системного аналізу, використання набутого досвіду у практичній діяльності керівника психологічної служби. Значна увага на даному етапі приділяється самостійному творчому пошуку, що супроводжується необхідним консультуванням та коригуванням;

на II етапі - імітаційно-рольового моделювання - керівники районних (міських) психологічних служб стають учасниками організаційно-діяльнісної гри. Розвивальний, креативний характер такої гри доведено практикою роботи;

на III етапі - рефлексивному - проводиться спільний (викладачів, тренерів та слухачів) аналіз проведеної роботи, дається оцінка кожному 3 етапів, вносяться пропозиції щодо удосконалення роботи, проходить самооцінка кожним своїх досягнень, накреслюються подальші шляхи саморозвитку та самовдосконалення.

\section{Список використаних джерел:}

[1] Панок, В. Г. (2020). Концепція психологічного супроводу освітніх реформ у діяльності психологічної служби. Вісник Національної академії педагогічних наук України, 2(1). Київ: НАПН

[2] Панок, В. Г., Лунченко, Н. В. (2018). Становлення психологічної служби системи освіти в контексті суспільних трансформацій в Україні. Вісник ХНПУ імені Г. С. Сковороди. Психологія (Вип. 58, с. 8-24). Харків: ХНПУ 